\title{
JUURNAL.RU
}

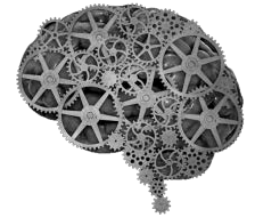

COMPANY GROUP "INTELLEKT"

Куртанидзе О.О., Живаева Ю.В. Красноярский государственный медицинский университет имени профессора В.Ф.Войно-Ясенеикого» Министерства здравоохранения РФ Красноярск, Россия

doi: 10.18411/lj2016-6-1-14

\section{Особенности проявления тревожности у студентов в предсессионный период}

Актуальность темы данной статьи обусловлена тем, что проблема изучения феномена тревожности в отечественной и зарубежной литературе в последнее время обсуждается очень активно. С одной стороны, подчеркивается, что адекватный уровень тревожности играет важную роль в эмоциональноволевой регуляции и в целом является существенным внутренним фактором, обусловливающим формирование адаптивного ресурса зрелой личности. С другой стороны, большинство авторов отмечает, что именно с высоким уровнем тревожности связаны трудности социально-психологической адаптации, формирования адекватного представления о себе и своих личностных качествах (В.М. Астапов, А.И. Захаров, Н.Д. Левитов, А.М. Прихожан и др.).

Изучением тревожности занимались многие известные психологи, такие как Зигмунд Фрейд, Карэн Хорни, Анна Фрейд, Дж. Тейлор, А. Прихожан, Ролло Мэй.

Психологи заметили, что обучение (познание нового, проверка полученных навыков и умений) всегда сопровождается повышением тревожности. Более того, некоторый оптимальный уровень тревожности активизирует обучение, делает его эффективнее. Здесь тревожность - фактор мобилизации внимания, памяти, интеллектуальных способностей. Но когда 
уровень тревожности превышает этот оптимальный предел, человека охватывает паника. Стремясь избежать неуспеха, он устраняется от деятельности, либо ставит все на достижение успеха в конкретной ситуации, и так изматывается, что «проваливается» в других ситуациях.

Эмоции и чувства представляют собой отражение реальной действительности в форме переживаний. По классификации предложенной К. Изардом, в его «теории дифференциации эмоций», выделяются эмоции фундаментальные и производные. К фундаментальным относятся: интерес волнение, радость, горе - страдание, удивление, гнев, отвращение, презрение, страх, стыд, вина. Остальные производные. Из соединения фундаментальных эмоций возникает комплексное, эмоциональное состояние, как тревожность, которая может сочетать в себе и страх, и гнев, и вину, и интерес - возбуждение.

Так что же такое тревожность? Разные авторы дают разные определения этому эмоциональному состоянию. Большой психологический словарь определяет тревожность, как индивидуальную психологическую особенность, проявляющуюся в склонности человека к частым и интенсивным переживаниям состояния тревоги, а также в низком пороге её возникновения.

В. В. Суворова в своей книге «Психофизиология стресса» определяет тревожность как психическое состояние внутреннего беспокойства, неуравновешенности и в отличие от страха может быть беспредметной и зависеть от чисто субъективных факторов, приобретающих значение в контексте индивидуального опыта. И относит тревожность к отрицательному комплексу эмоций, в которых доминирует физиологический аспект.

А. М. Прихожан, определяет тревожность, как устойчивое личностное образование, сохраняющееся на протяжении достаточно длительного периода времени.

Как и любое комплексное психологическое образование, тревожность характеризуется сложным строением, включающим когнитивный, эмоциональный и операционный аспекты, при доминировании эмоционального. 
В целом, тревожность - это субъективное проявление неблагополучия личности, ее дезадаптации. Тревожность как переживание эмоционального дискомфорта, предчувствие грядущей опасности, является выражением неудовлетворения значимых потребностей человека.

Сейчас студентами принято считать молодых людей в возрасте от 18 до 25 лет. По международной классификации, завершение юности и начало взрослости начинается для женщины с 20 лет, а для мужчины - с 21 года. Откуда следует, что основная масса студентов завершает в период обучения в вузе свою фазу юности и переходит в фазу взрослости. В переводе с латинского слово «студент» означает - усердно работающий, занимающийся, то есть овладевающий знаниями. Студенчество это сложный период, во время которого происходит становления человека, становление его личности, происходит всестороннее развитие, как его старых интересов, так и появление, и развитие новых.[2]

Возраст 18-25 лет - это период наиболее активного развития нравственных и эстетических чувств, становления и стабильности характера, овладения полным комплексом социальных ролей взрослого человека. Этот возраст характерен также тем, что этот период является сенситивным для развития интеллектуальных и физических сил.

Время учебы в вузе, совпадает с периодом юности. Изучением этого возрастного периода занимались такие ученые как: Б.Г. Ананьев, А.В. Дмитриев, З.Ф. Исаева, В.Т. Лисовский, И.С. Кон и другие.

В.И. Слободчиков считает, что юность является завершающей стадией ступени персонализации. В виде главных новообразований этого возраста он выделяет: саморефлексию, осознание собственной индивидуальности, появление жизненных планов, готовность к самоопределению, установка на сознательное построение собственной жизни, постепенное врастание в различные сферы жизни [1]. 
Юность выступает как период принятия ответственных решений, определяющих всю дальнейшую жизнь студента: выбор профессии и своего места в жизни, жизненной позиции, выбор спутника жизни, создание своей семьи. Поступление в вуз укрепляет веру студента в собственные силы и способности, порождает надежду на интересную жизнь. В связи с этим на втором и третьем курсах часто возникают вопросы о правильности выбора вуза, специальности, профессии. К концу третьего курса окончательно решается вопрос о профессиональном самоопределении.

Студенческий возраст характеризуется большой дифференцированностью эмоциональных реакций и способов выражения эмоциональных состояний, а так же повышение самоконтроля и саморегуляции. В качестве общих особенностей этого возраста отмечается изменчивость настроений с переходами от безудержного веселья к унынию и сочетание ряда полярных качеств, выступающих попеременно. К ним относятся особая сенситивность чувствительность к оценки другими своей внешности, способностей, умений, и наряду с этим, излишняя самоуверенность и чрезмерная критичность в отношении окружающих. А студентам, как и подросткам свойственно повышенное внимание к представлениям о норме в отношении роста тела, его размера, веса, поведения, и движения. Они склонны находить у себя физические отклонения даже в тех случаях, когда все показатели соответствуют норме. Эта повышенная чувствительность может вызывать конфликтные реакции или даже хронические психические нарушения невротического характера, способствующие снижению самооценки [4].

Для студенческого возраста остается важным общение со сверстниками. Сознание групповой принадлежности, солидарности, дружеской взаимопомощи создает чрезвычайное чувство эмоционального благополучия и устойчивости. Юношеская общительность часто бывает эгоцентричной, а потребность в самовыявлении, раскрытие своих переживаний - выше интереса к чувствам и переживаниям другого. Отсюда возникает - эмоциональная напряженность в 
отношениях, неудовлетворенность ими. Юношеские группы удовлетворяют в первую очередь потребность в свободном, паритетном, эмоционально насыщенном общении. Свободное общение не просто способ проведение досуга, но и средство самовыражения, установления новых контактов, поиск себя. Принадлежность к компании повышает уверенность студента в себя и дает дополнительные возможности самоутверждения, способствует повышению самооценки. Так же в этот период формируется целостное представление о самом себе, отношение к себе, причем вначале осознаются и оцениваются студентом особенности его тела, внешности, привлекательности, а затем уже морально-психологические, интеллектуальные, волевые качества.

Определенный уровень тревожности - естественная и обязательная особенность активной деятельности личности. У каждого человека существует свой оптимальный или желательный уровень тревожности - это так называемая полезная тревожность. Оценка человека своего состояния в этом отношении является для него существенным компонентом самоконтроля и самовоспитания. Однако повышенный уровень тревожности является субъективным проявлением неблагополучия личности [2].

Высокотревожные студенты склонны воспринимать угрозу своей самооценке и жизнедеятельности в обширном диапазоне ситуаций и реагировать весьма напряженно, выраженным состоянием тревожности.

Обычно, тревожные студенты - это очень неуверенные в себе люди, с неустойчивой самооценкой. Постоянно испытываемое ими чувство страха перед неизвестным приводит к тому, что они крайне редко проявляют инициативу, предпочитают не обращать на себя внимание окружающих, ведут себя примерно, стараются точно выполнять требование - не нарушают дисциплину. Таких людей называют скромными, застенчивыми.

Когда же этот уровень превышает оптимальный, можно говорить о проявлении повышенной тревожности. Повышенный уровень может свидетельствовать о недостаточной эмоциональной приспособленности к тем 
иным социальным ситуациям. У студентов с данным уровнем проявляется отношение к себе как к слабому, неумелому. Тревожность окрашивает в мрачные тона отношение к себе, другим людям и действительности [2].

С целью изучения тревожности у студентов-третьекурсников нами было организовано и проведено исследование на базе кафедры психологии и педагогики с курсом медицинской психологии, психотерапии и педагогики ПО Красноярского Государственного Медицинского университета. Выборка исследования: 20 человек. Средний возраст исследуемых от 19 до 21 лет.

С целью исследования тревожности в качестве диагностического инструментария мы использовали экспресс-диагностику уровня социальной фрустрированности (Л.И. Вассерман), Шкалу Бека для оценки депрессии.

В результате исследования показателей тревожности по методикам диагностики тревожности были получены следующие результаты, по шкале Бека у 64\% исследуемых депрессия отсутствует; у 6\% легкая депрессия; умеренная депрессия не наблюдается у испытуемых; 18\% с выраженной депрессией; у 6\% выявлена тяжелая депрессия. Уровень социальной фрустрированности: у 45,50\% -низкий; у 45,50\% наблюдается средний уровень; и лишь у 5\% высокий уровень фрустрированности.

Тревожные студенты, как правило, не пользуются всеобщим признанием в группе, но и не оказываются в изоляции; они чаще входят в число наименее популярных, так как очень часто неуверенны в себе, замкнуты, малообщительны, или же напротив, сверхобщительные, назойливые или озлобленные. Также причиной непопулярности является их безынициативность из-за своей неуверенности в себе, следовательно, эти студенты не всегда могут быть лидерами в межличностных взаимоотношениях.

Подводя итог, тревожность влияет на межличностное взаимодействие студентов, на само поведение, а, следовательно, и на учёбу. Студенты, имеющие высокий уровень тревожности не могут быть лидерами, т.к. не уверены в себе, замкнуты, стеснительны, не общительны. Как правило, такие студенты одиноки. 
Повышенный уровень тревожности может свидетельствовать о недостаточной эмоциональной приспособленности к ситуации, в которой находится студент.

\section{Литература:}

1. Габдреева, Г.Ш. Формирование способности к самоуправлению психическими состояниями у студентов с высоким уровнем тревожности: Автореф. дис. канд. психол. наук. - М., 1991.

2. Василюк, Ф.Е. Психология переживания: Анализ преодоления психических ситуаций - М.: Издательство МГУ, 1980.

3. Волков, Б.С. Психология юности и молодости / Учебное пособие. - М.: Академический Проект: Трикста,2006. - 256 с. 